Article

\title{
The Trade Network Structure of the "One Belt and One Road" and Its Environmental Effects
}

\author{
Shaowei Chen ${ }^{1}$ and Qiang (Patrick) Qiang ${ }^{2, *(\mathbb{D})}$ \\ 1 School of Economics, Xi'an University of Finance and Economics, Xi'an 710100, China; chensw@xaufe.edu.cn \\ 2 Great Valley School of Graduate Professional Studies, Pennsylvania State University, Malvern, \\ PA 19355, USA \\ * Correspondence: qzq10@psu.edu; Tel.: +1-610-725-5282
}

Received: 1 April 2020; Accepted: 23 April 2020; Published: 25 April 2020

check for updates

\begin{abstract}
Using bilateral trade data along the "One Belt and One Road" (OBOR) from 2005-2016, this paper analyzes the structure and characteristics of the OBOR trade network. We find that the centrality, clustering coefficient, eigenvector centrality and average node strength are generally increasing, and China holds the core position in the network. Furthermore, we use three-stage least squares (3SLS) for analysis of the relationship between CO2 emissions and trade network characteristics and find that the status of country nodes in the trade network has a significant impact on $\mathrm{CO} 2$ emissions, with differences between high- and low-income countries. Our results provide additional insights regarding the impacts of the characteristics of the OBOR trade network on $\mathrm{CO} 2$ emissions.
\end{abstract}

Keywords: "One Belt and One Road"; complex network; trade network; structure characteristics; network analysis; environmental effects

\section{Introduction}

In September 2013, Chinese President Xi Jinping proposed the "One Belt and One Road" (OBOR) initiative, which includes the countries along the Silk Road Economic Belt and the 21st Century Maritime Silk Road. The OBOR initiative involves approximately 66 countries that contribute more than $40 \%$ of the world's gross domestic production and facilitates cooperation in finance, infrastructure investment and trade [1]. The OBOR runs through the Eurasian-African continent, connecting an active East Asian economic circle and a developed European economic circle with the vast inland countries in the middle that have great potential for economic development. The natural resources of the countries along the OBOR are different, and therefore, the competitive advantages of these countries are distinctive and sometimes complementary. With the strengthening of economic and trade cooperation, countries along the OBOR route will become the new engine of world economic development. Cooperative trading relationships among the countries along the route form the basis of the OBOR initiative and hence deserve more attention. However, while most countries prioritize economic and trade development, they tend to ignore the environmental impacts resulting from economic prosperity. In the past decade, we have witnessed a recording-breaking number of natural disasters, which have caused a tremendous amount of damage to societies. Developing countries are often caught off-guard when facing these disasters and hence have been hit the hardest. Studies show that $20 \%-33 \%$ of global carbon emissions are related to the international trade [2]. Hence, it is crucial and relevant to study the environmental impact of trade along the OBOR to analyze the special characteristics of the OBOR network and therefore, provide insights for government policy makers.

In recent years, network analysis has been widely used in international trade research to analyze the characteristics of the world trade system. The first few studies to use complex networks to analyze 
international trade include Snyder et al. [3] and Smith et al. [4], who studied the trade network and discussed the structure of the world economic system. The stream of research that followed their work has discussed the evolution, structure and statistical characteristics of trade networks [5-7]. However, most studies focus on the world trade network, and very limited research covers regional trade networks, such as the OBOR initiative.

May [8] classified the existing studies about the relationship between international trade and the environment into four categories depending on their focus: environmental damage, market structure, international agreements, and specific ways free trade affects the environment. Furthermore, the author introduced the international social network model, which treats environmental issues and the international trade system as a whole. Aller et al. [9] identified the most important countries in the world trade network, and analyzed how the network or indirect effects from trade affect the environmental quality of a country. According to the above authors, in a trade network, the trade relations between country $c$ and country $d$ have effects on the trade relations between country $a$ and country $b$, which can be called the indirect effects of trade. On the other hand, the effects of import and export on economic development represent the direct effects of trade.

Hakimi and Hamdi [10] analyzed trade data between Tunisia and Morocco with the rest of the world and found that trade liberalization and foreign direct investment (FDI) caused increasing CO2 emissions. By studying developed and developing countries separately, Essandoh et al. [11] finds that for developed countries, $\mathrm{CO} 2$ emissions negatively correlate with trade, while they have a positive relationship with FDI inflows for developing countries. Fernández-Amador et al. [12] study the dataset including geographical production-based inventories, final production- and consumption-based inventories to study the evolution of $\mathrm{CO} 2$. The authors find that to protect the environment effectively, one has to analyze emissions across the trading border and across the life-cycle of the product. On the other hand, by using the geographical variables from the gravity model, Frankel and Rose [13] found no significant evidence that the globalization of trade has detrimental effects on the environment. However, the authors pointed out that the findings agreed with the Kuznets curve, which states that trade harms low-income countries and benefits high-income countries. For a comprehensive review of the theory and empirical studies related to the environmental consequences of economic growth and international trade, please refer to the study by Copeland and Taylor [14]. Wang et. al [15] analyzed the evolution of the global coal trade network using the complex network approach. The authors found that network centralities moved to Asia from North America and that the flow distribution of the network become more unevenly distributed, which leads to increasing $\mathrm{CO} 2$ emissions in Asia. However, the paper only summarizes the descriptive nature of the network and do not study the empirical relationships between the network indicators and the emissions.

In recent years, some researchers focus on the environmental issues of OBOR economies, especially on the area of the impacts of $\mathrm{CO} 2$ emissions. For example, Sun et. al [16] use the logarithmic mean divisia index method to analyze the ecological pressure of carbon footprint in OBOR countries. Hafeez et. al [17], on the other hand, analyze the panel data and find that financial development, urban population, and FDI have negative effects on carbon footprint while economic growth and energy consumption increase the carbon footprint. However, these studies do not examine the trade effect on the environmental quality. In our analysis of the development of the OBOR initiative, we take on the task of comparing the environmental impact of the OBOR trade network with the findings of the existing literature (cf. [9]). In particular, we want to see whether there are any special characteristics of the interaction between the OBOR trade network and the environment. Moreover, motivated by the research by Wang et. al. [15], we add additional network indicators, such as weighted in and out degree and clustering, to explore further relationship between the trade network and emissions.

In this paper, we consider the environmental issues within the OBOR trade system. In particular, we analyze the structure of the OBOR trade network and discuss the direct and indirect effects of trade on environmental quality. According to Johnson et al. [18], environmental quality refers to the condition 
of the living environment required by human beings and other species and can be evaluated by a series of measures. In this paper, we focus on emissions, an important measure of environmental quality.

The paper is structured as follows. In Section 2, we analyze the structure of the OBOR trade network and investigate the relationship between international trade and the environment. Section 3 demonstrates and analyzes the indirect effects of trade and the direct effects of trade on the environment. This paper concludes in Section 4.

\section{An Overview of the OBOR Trade Network and its Environmental Effects}

\subsection{The OBOR Trade Network}

The OBOR trade network can be represented as a weighted network $G=(V, W)$, where $V=\left\{v_{1}, v_{2}\right.$, $\left.\ldots, v_{n}\right\}$ is a set of vertexes with $v_{i}$ representing a country in the trade network and $V(t)$ represents the total number of countries in the OBOR trade network in year $t ; W=\left\{w_{i j}\right\}$ is a set of weighted edges in the network, where $w_{i j}>0$ represents the trade flow from country $i$ to country $j$, and $w_{i j}=0$ denotes that there is no trade relationship between $i$ and $j$. According to other studies (cf. [19,20]), the edge weight between countries $i$ and $j$ is defined as $w_{i j}=\frac{1}{2}\left(\frac{E_{i j}}{G D P_{i}}+\frac{I_{i j}}{G D P_{j}}\right)$, where $E_{i j}$ is the export volume of country $i$ to country $j, I_{i j}$ denotes the import volume of country $i$ from country $j$, and $G D P_{i}$ and $G D P_{i}$ denote the gross domestic product of country $i$ and country $j$, respectively.

In this paper, we choose 66 countries along the OBOR from 2005-2016 to build the OBOR trade network. The relevant data, mainly the bilateral import and export data of the sample countries, come from the United Nations Conference on Trade and Development database for the period 2005-2016. The network is a typical complex network system with weighted directed links, in which the direction of an edge is determined by the flow of import and export trade between the two connected countries. The network topology can be represented by adjacent matrix $A=\left(a_{i j}\right)$, where $a_{i j}=\left\{\begin{array}{l}1, \text { if } w_{i j}>0 \\ 0, \text { if } w_{i j}=0\end{array}\right.$. The trade network over the time horizon can be defined as a set of $N \times N$ adjacent matrices, and the weighted edge vector is expressed as $G_{t}=\left\{A^{t}, W^{t}\right\}$, with $t$ from 2005 to 2016 . All countries along the OBOR are denoted as vertexes in the network, and a directed weighted network is constructed according to their bilateral trade relations. To illustrate the evolution characteristics of the trade network topology, we choose the geographical flowcharts of the OBOR trade network in 2005, 2010 and 2016 (see Figure 1).

Figure 1 shows that the strength of the trade network has increased significantly since 2005. Trade links between countries along the route have become increasingly closer, and trade flows have increased significantly. With regard to network nodes, China, Singapore, Malaysia, Indonesia, India, Russia, Turkey, the United Arab Emirates, Poland and the Czech Republic are important nodes in the trade network because these countries are either centers or regional centers. Moreover, based on the tightness of internal links, which can be measured by the trade flow volume among the countries in the trade network, all of the countries can be roughly divided into three sectors: Southeast Asia, Central and Eastern Europe and Midwest Asia. China is the central node of the whole trade network. Among the three sectors, Southeast Asian countries form the largest cluster of countries, with Singapore, Malaysia and Indonesia as the central nodes. Central and Eastern European countries form the second largest cluster, with Russia, the Czech Republic and Poland as the central nodes. Finally, the smallest cluster is located in the Midwest Asia sector, with India, Turkey and the United Arab Emirates as the central country nodes. All countries of OBOR trade network are shown in Table 1. 


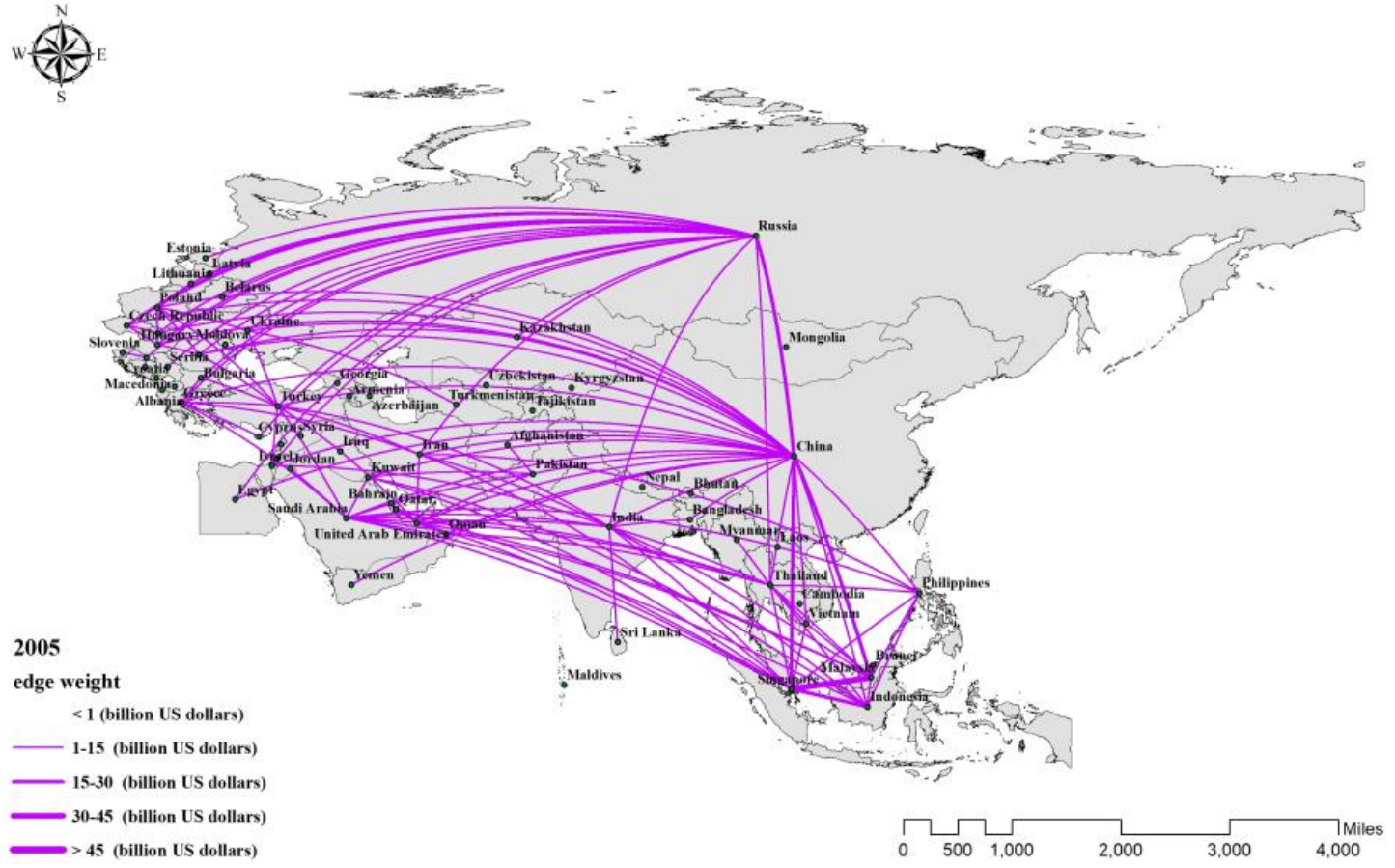

(a)

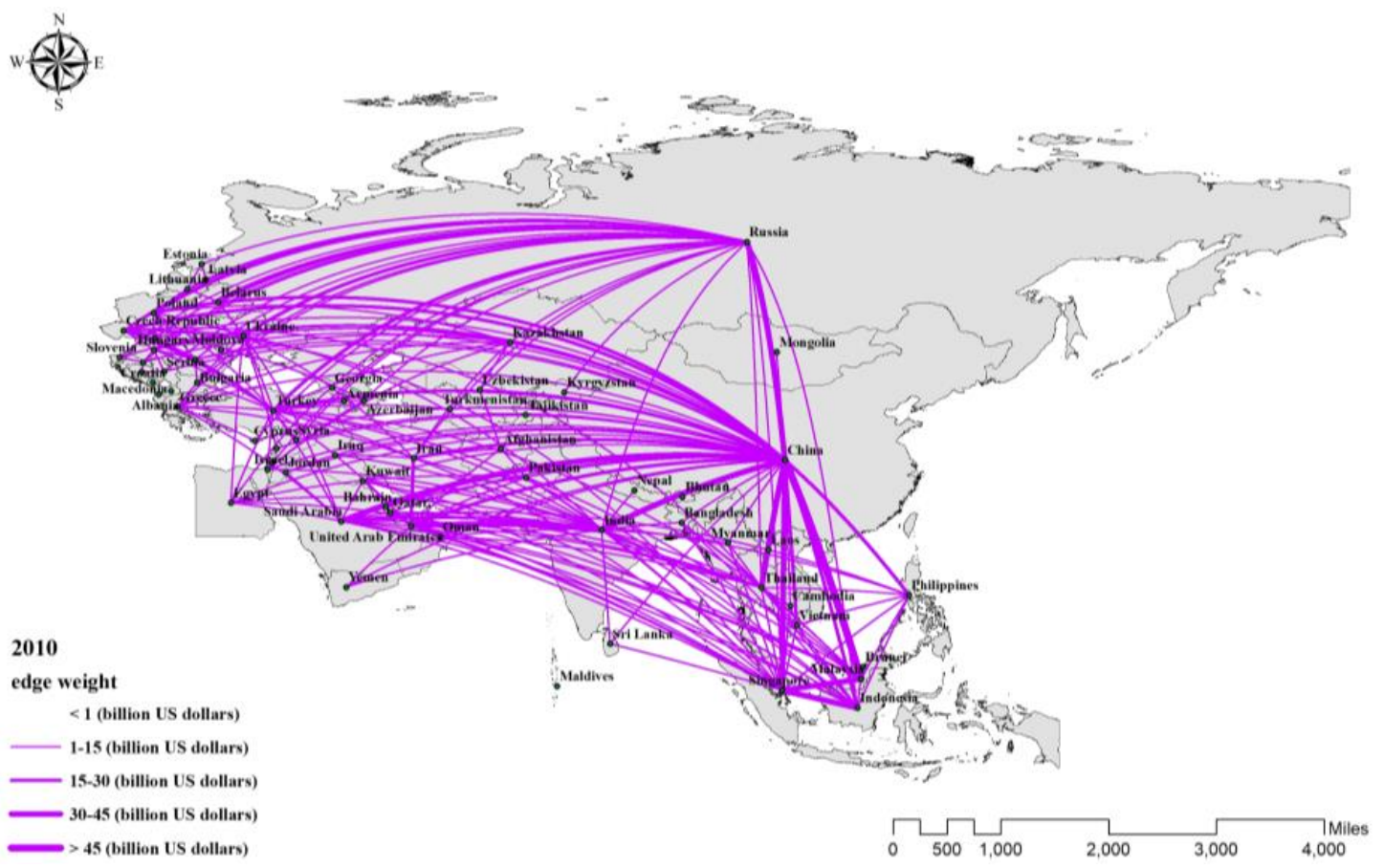

(b)

Figure 1. Cont. 


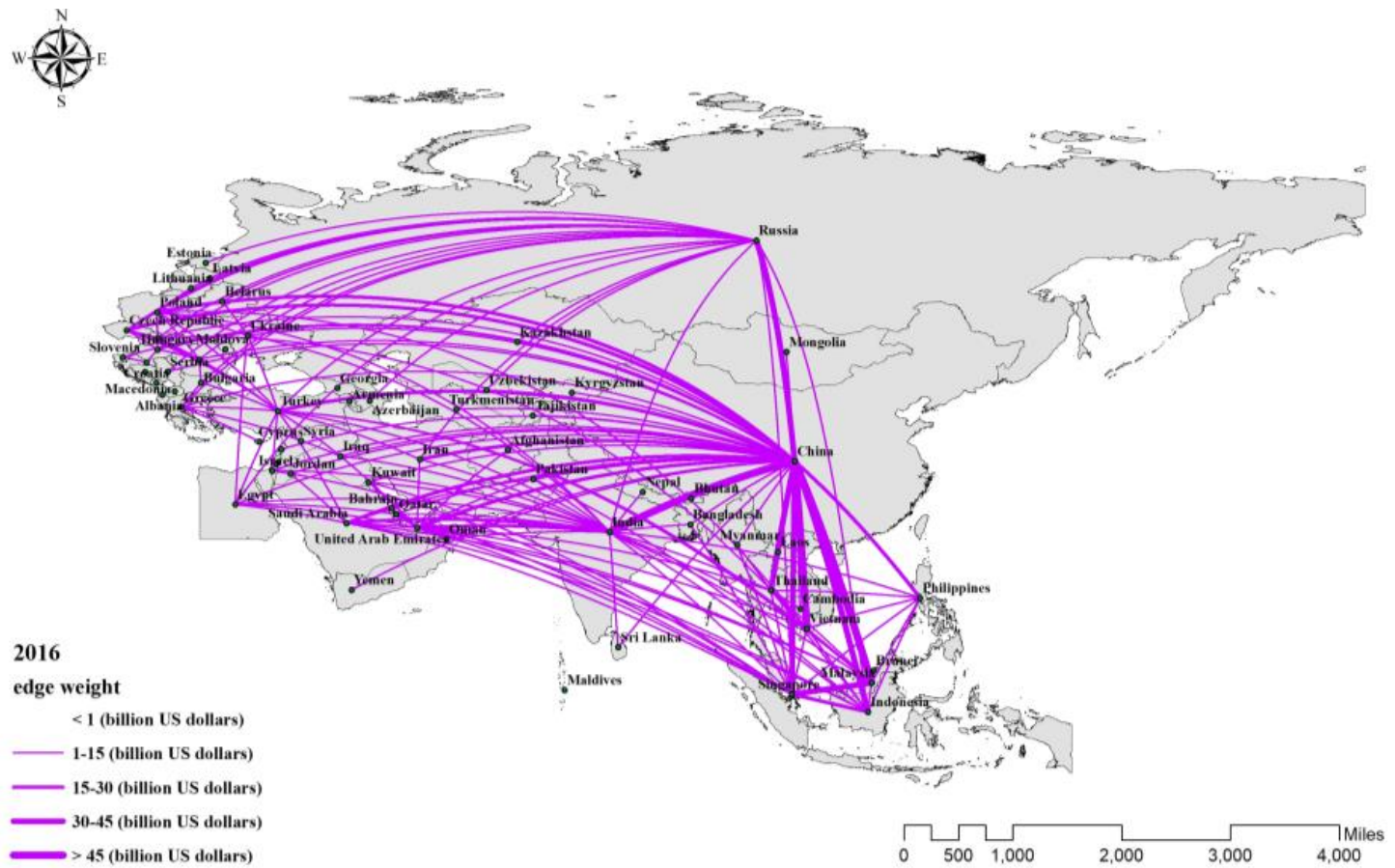

(c)

Figure 1. OBOR trade network. (a): in 2005; (b): in 2010; (c): in 2016; Note: The edge weight in Figure 1 is measured by the bilateral trade volume of the sample countries.

Table 1. The countries in the OBOR trade network.

\begin{tabular}{|c|c|c|c|c|c|c|c|}
\hline No. & Country Name & No. & Country Name & No. & Country Name & No. & Country Name \\
\hline 1 & Afghanistan & 21 & Hungary & 41 & Myanmar & 61 & Turkmenistan \\
\hline 2 & Albania & 22 & India & 42 & Nepal & 62 & Ukraine \\
\hline 3 & Armenia & 23 & Indonesia & 43 & Oman & 63 & $\begin{array}{l}\text { United Arab } \\
\text { Emirates }\end{array}$ \\
\hline 4 & Azerbaijan & 24 & Iran & 44 & Pakistan & 64 & Uzbekistan \\
\hline 5 & Bahrain & 25 & Iraq & 45 & State of Palestine & 65 & Vietnam \\
\hline 6 & Bangladesh & 26 & Israel & 46 & Philippines & 66 & Yemen \\
\hline 7 & Belarus & 27 & Jordan & 47 & Poland & & \\
\hline 8 & Bhutan & 28 & Kazakhstan & 48 & Qatar & & \\
\hline 9 & $\begin{array}{c}\text { Bosnia } \\
\text { Herzegovina }\end{array}$ & 29 & Kuwait & 49 & Romania & & \\
\hline 10 & $\begin{array}{c}\text { Brunei } \\
\text { Darussalam }\end{array}$ & 30 & Kyrgyz & 50 & Russian & & \\
\hline 11 & Bulgaria & 31 & Lao PDR & 51 & Saudi Arabia & & \\
\hline 12 & Cambodia & 32 & Latvia & 52 & Serbia & & \\
\hline 13 & China & 33 & Lebanon & 53 & Singapore & & \\
\hline 14 & Croatia & 34 & Lithuania & 54 & Slovakia & & \\
\hline 15 & Cyprus & 35 & Macedonia & 55 & Slovenia & & \\
\hline 16 & Czech Republic & 36 & Malaysia & 56 & Sri Lanka & & \\
\hline 17 & Egypt & 37 & Maldives & 57 & Syria & & \\
\hline 18 & Estonia & 38 & Moldova & 58 & Tajikistan & & \\
\hline 19 & Georgia & 39 & Mongolia & 59 & Thailand & & \\
\hline 20 & Greece & 40 & Montenegro & 60 & Turkey & & \\
\hline
\end{tabular}




\subsection{The Network Structure Analysis}

The topological structure of the OBOR trade network reveals some special properties. Some topological characteristics would not be captured by the graph of network structure, and therefore, it is appropriate to study the topological structure of the trade network by using certain existing network metrics. Below, we introduce the measures used in this paper to analyze the structural characteristics of trade networks.

Closeness centrality measures the total distance from other nodes to a given node. The stronger the centrality of one node is, the smaller the total distance to the node. A node is the topological center of the network if its total distance is the smallest. In addition, a weighted distance based on total bilateral trade can be used to capture the centrality of country nodes in the trade network. In the trade network, the higher the closeness centrality of country $i$, the closer its trade connection with other countries in the trade network. The formula is as follows:

$$
\text { Closeness }_{i}=\frac{n-1}{\sum_{i \neq j} l_{i j}}
$$

where $n$ is the number of nodes in the OBOR trade network $G$, and $l_{i j}$ denotes the shortest distance between nodes $i$ and $j$ in network $G$, which is measured by the weighted distance based on bilateral trade data.

Betweenness centrality is another centrality measure that reflects the importance of node $i$ in the process of connecting nodes $k$ and $j$ and captures the criticality of country $i$ in the trade between the other two countries. The larger the betweenness centrality of country $i$, the more important node $i$ is in the trade relations of the other two countries and the stronger its role in the intermediary trade of the other countries. The calculation is as follows:

$$
\text { Betweenness }_{i}=\sum_{k \neq j: i \notin\{k, j\}} \frac{P_{i}(k j) / P(k j)}{(n-1)(n-2) / 2}
$$

where $P_{i}(k j)$ denotes the number of shortest paths passing through node $i$ between nodes $k$ and $j$, and $P(k j)$ denotes the total number of shortest paths between nodes $k$ and $j$.

Eigenvector centrality measures the connectivity between a country node and many other "central" countries. Its size depends on the centrality of its large trade partners. The greater the eigenvector centrality of country $i$, the more central country nodes it connects, which indicates a closer trade relationship between country $i$ and the central countries of the trade network. The formula is as follows:

$$
\lambda C^{e}(G)=A C^{e}(G)
$$

where $\lambda C^{e}(G)=\sum_{j} a_{i j} C^{e}(G)$; i.e., the centrality of a country is proportional to the sum of the centralities of its trade partners, and the proportional factor is given by $\lambda$. From Formula (3), we can find that $C^{e}(G)$ is the eigenvector of adjacent matrix $A$ and its corresponding eigenvalue is $\lambda$.

Node strength or weighted degree reflects the trade intensity of a country with other countries in the trade network, or the tightness of the trade links between countries. This indicator considers not only the number of neighboring nodes, but also the edge weight between the node and its neighboring nodes. The calculation formula is as follows:

$$
S_{i}=\sum_{j \in N_{i}} w_{i j}
$$

where $w_{i j}$ is the edge weight between nodes $i$ and $j$, and $N_{i}$ is a set of adjacent nodes of node $i$. Based on the above, we can further investigate the weighted indegree (import strength) and weighted outdegree (export strength) of nodes in the trade network. 
Clustering reflects another important feature of the network, which is how its nodes are assembled together, i.e., the aggregating and grouping characteristics of the network. In the trade network, this indicator reflects the transitivity degree of the network. The clustering coefficient of a country node reflects its cohesion and radiation force in the trade network. If the edges start from the same node, such as distance $i j$ and $i k$, which both contain node $i$, then the clustering coefficient of node $i$ can be calculated as

$$
\text { Clustering }_{i}=\frac{1}{S_{i}\left(d_{i}(G)-1\right)} \sum_{j, k \in g} \frac{w_{i j}+w_{j k}}{2} \frac{w_{j i}+w_{k j}}{2} a_{i j} a_{j k} a_{k i}
$$

where $d_{i}(G)$ is the degree of node $i$ in network $G$, which is the number of adjacent nodes of node $i$, and $a_{i j}, a_{j k}$ and $a_{k i}$ refer to whether there is a connection between nodes $i, j$ and $k$.

The OBOR trade network is a directed weighted network, and its overall characteristics can be measured by the average network statistics. Table 2 shows time-specific information regarding the main statistical indicators of the OBOR trade network in 2005-2016. Except for a large fluctuation in 2016, the trend in other years is relatively consistent. The closeness centrality, clustering coefficient, eigenvector centrality and average node strength of the trade networks generally increase, while the betweenness centrality declines somewhat. The decline of betweenness centrality could be partly due to China's entrance to the WTO. With China being the largest central country of the OBOR trade network, many of China's transshipment port trade has turned into direct trade since it joined the WTO, which may have caused the betweenness centrality of the network to decline. However, there is a spike in the betweenness centrality of the OBOR trade network in 2016. We believe it is partly due to the impact of the Syrian refugee crisis on neighboring countries and European countries. Most of these countries' betweenness centrality more than doubled in 2016 compared to 2015 (e.g. Albania, Bulgaria, Georgia, Greece, Jordan, Turkey, etc.)

Table 2. Statistical indicators of OBOR trade networks in 2005-2016.

\begin{tabular}{cccccc}
\hline Year & $\begin{array}{c}\text { Closeness } \\
\text { Centrality }\end{array}$ & $\begin{array}{c}\text { Betweenness } \\
\text { Centrality }\end{array}$ & Clustering & $\begin{array}{c}\text { Eigenvector } \\
\text { Centrality }\end{array}$ & $\begin{array}{c}\text { Weighted } \\
\text { Degree }\end{array}$ \\
\hline 2005 & 0.881 & 10.722 & 0.893 & 0.869 & 0.590 \\
2006 & 0.897 & 9.075 & 0.894 & 0.891 & 0.660 \\
2007 & 0.897 & 9.108 & 0.899 & 0.893 & 0.671 \\
2008 & 0.894 & 9.385 & 0.894 & 0.888 & 0.676 \\
2009 & 0.894 & 9.523 & 0.892 & 0.885 & 0.573 \\
2010 & 0.911 & 7.969 & 0.908 & 0.905 & 0.660 \\
2011 & 0.912 & 7.738 & 0.911 & 0.907 & 0.737 \\
2012 & 0.912 & 7.738 & 0.911 & 0.908 & 0.736 \\
2013 & 0.916 & 7.275 & 0.916 & 0.913 & 0.727 \\
2014 & 0.906 & 8.077 & 0.908 & 0.903 & 0.703 \\
2015 & 0.918 & 7.154 & 0.918 & 0.915 & 0.674 \\
2016 & 0.864 & 12.507 & 0.876 & 0.853 & 0.528 \\
\hline
\end{tabular}

Note: These values are obtained by averaging all countries' indicators for each year in 2005-2016. 
From the node attributes of the trade network, Table 3 shows the top five and the bottom three countries in each statistical indicator of the OBOR trade network in 2005, 2010 and 2016. The results are as follows: (1) Comparing the rankings of network indicators in 2005, 2010 and 2016, we can find that China ranks in the top five of all trade network indicators, except for the clustering coefficient. It means that China has good trade relations with all other countries in the OBOR trade network and does not exist the "rich man's club" phenomenon. In particular, China ranks first in the centrality indicators of closeness centrality, betweenness centrality and weighted degree. It ranked second for both weighted indegree and weighted outdegree in 2005 and first in 2010 and 2016. All the above indicates that China is one of the "central" country nodes and holds the core position in the OBOR trade network. (2) Comparing the changes in China's network characteristics between 2010 and 2016, we find that the values of China's network indicators have improved to varying degrees. It ranks at the top for all indicators except the clustering coefficient. This indicates that, after the OBOR initiative was put forward, China actively deepened its economic and trade cooperation with the countries along its borders and increased its bargaining power in the trade network. (3) In addition to China, the Czech Republic, Poland, Greece and the United Arab Emirates rank high in closeness centrality, which indicates that their "distance" in the trade with other countries is relatively short, and their trade is efficient. The Czech Republic, Poland, Turkey, Malaysia, and Indonesia rank relatively high in betweenness centrality, indicating that they serve as "bridges" and "intermediaries", promoting trade links among countries in the region and that their participation in the trade network is fairly active. Greece, the Czech Republic, Poland, Russia, Malaysia, and Indonesia rank high in eigenvector centrality, which shows that they have high connectivity with the central country nodes in the trade network. Singapore, India, Russia, Thailand, the United Arab Emirates and Tajikistan rank high in weighted degree, weighted indegree and weighted outdegree, which shows that they have a certain degree of independence in import and export trade and have strong trade links with other countries in the network. (4) In addition, we can find that Bhutan, Laos, Brunei, Montenegro and some other countries are ranked very low in other network indicators, which means that these countries are at the periphery of the trade network. This is because these are all small countries with less diverse domestic industrial structures, low trade volumes, and low degrees of integration into the trade network. On the other hand, these countries have high clustering coefficient scores, which means that they depend on large trading countries. 
Table 3. Top five and last three countries ranked by network statistical indicators in the OBOR trade network in 2005, 2010 and 2016.

\begin{tabular}{|c|c|c|c|c|c|c|c|c|c|c|c|c|c|c|}
\hline \multirow{2}{*}{ Rank } & \multicolumn{2}{|c|}{ Closeness Centrality } & \multicolumn{2}{|c|}{ Betweenness Centrality } & \multicolumn{2}{|c|}{ Clustering } & \multicolumn{2}{|c|}{ Eigenvector Centrality } & \multicolumn{2}{|c|}{ Weighted Indegree } & \multicolumn{2}{|c|}{ Weighted Outdegree } & \multicolumn{2}{|c|}{ Weighted Degree } \\
\hline & Country & Score & Country & Score & Country & Score & Country & Score & Country & Score & Country & Score & Country & Score \\
\hline \multicolumn{15}{|c|}{2005} \\
\hline 1 & China & 1 & China & 54.958 & Montenegro & 1 & Czech Republic & 1 & China & 1.092 & Russian & 2.305 & Russian & 3.191 \\
\hline 3 & Poland & 1 & Malaysia & 22.431 & Lao PDR & 0.985 & Malaysia & 1 & Russian & 0.887 & Singapore & 1.433 & Singapore & 2.430 \\
\hline 4 & Sri Lanka & 1 & Pakistan & 20.564 & Bhutan & 0.984 & Romania & 1 & Malaysia & 0.673 & India & 0.827 & India & 1.477 \\
\hline 5 & $\begin{array}{l}\text { United Arab } \\
\text { Emirates }\end{array}$ & 1 & Poland & 20.564 & Myanmar & 0.981 & Slovenia & 1 & India & 0.650 & Ukraine & 0.797 & Ukraine & 1.255 \\
\hline 64 & Maldives & 0.660 & Bhutan & 0.162 & Poland & 0.843 & Lao PDR & 0.409 & Lao PDR & 0.006 & Lao PDR & 0.003 & Lao PDR & 0.009 \\
\hline 65 & Bhutan & 0.593 & Lao PDR & 0.055 & $\begin{array}{l}\text { United Arab } \\
\text { Emirates }\end{array}$ & 0.843 & Bhutan & 0.367 & Nepal & 0.003 & Montenegro & 0.003 & Nepal & 0.007 \\
\hline 66 & Montenegro & 0.508 & Montenegro & 0.000 & China & 0.818 & Montenegro & 0.000 & Montenegro & 0.000 & Afghanistan & 0.001 & Montenegro & 0.003 \\
\hline \multicolumn{15}{|c|}{2010} \\
\hline 1 & Bulgaria & 1 & China & 15.581 & Bhutan & 0.987 & China & 1 & China & 1.004 & China & 2.264 & China & 3.268 \\
\hline 2 & China & 1 & Czech Republic & 15.581 & $\begin{array}{c}\text { Brunei } \\
\text { Darussalam }\end{array}$ & 0.981 & Czech Republic & 1 & Russian & 0.930 & Russian & 2.061 & Russian & 2.991 \\
\hline 3 & Czech Republic & 1 & Malaysia & 15.581 & Turkmenistan & 0.977 & Malaysia & 1 & Singapore & 0.890 & India & 1.164 & Singapore & 2.047 \\
\hline 4 & Egypt & 1 & Poland & 15.581 & Tajikistan & 0.975 & Poland & 1 & India & 0.862 & Singapore & 1.157 & India & 2.026 \\
\hline 5 & Hungary & 1 & Turkey & 15.581 & Iraq & 0.974 & Russian & 1 & Thailand & 0.647 & Thailand & 0.852 & Thailand & 1.499 \\
\hline 64 & Maldives & 0.677 & $\begin{array}{c}\text { Brunei } \\
\text { Darussalam }\end{array}$ & 0.446 & Turkey & 0.875 & Lao PDR & 0.612 & Tajikistan & 0.010 & Tajikistan & 0.009 & Tajikistan & 0.019 \\
\hline 65 & Montenegro & 0.677 & Turkmenistan & 0.351 & Ukraine & 0.875 & Bhutan & 0.504 & $\begin{array}{c}\text { Brunei } \\
\text { Darussalam }\end{array}$ & 0.007 & $\begin{array}{c}\text { Brunei } \\
\text { Darussalam }\end{array}$ & 0.002 & $\begin{array}{c}\text { Brunei } \\
\text { Darussalam }\end{array}$ & 0.009 \\
\hline 66 & Bhutan & 0.631 & Bhutan & 0.113 & $\begin{array}{l}\text { United Arab } \\
\text { Emirates }\end{array}$ & 0.875 & $\begin{array}{l}\text { State of } \\
\text { Palestine }\end{array}$ & 0.429 & Mongolia & 0.003 & Mongolia & 0.001 & Mongolia & 0.004 \\
\hline \multicolumn{15}{|c|}{2016} \\
\hline 1 & China & 1 & China & 27.659 & Syria & 0.995 & $\begin{array}{c}\text { Bosnia } \\
\text { Herzegovina }\end{array}$ & 1 & China & 1.218 & China & 2.392 & China & 3.611 \\
\hline 2 & Croatia & 1 & Czech Republic & 27.659 & Bhutan & 0.991 & China & 1 & Russian & 0.714 & Russian & 1.422 & Russian & 2.136 \\
\hline 3 & Czech Republic & 1 & Indonesia & 27.659 & Iraq & 0.990 & Czech Republic & 1 & Singapore & 0.536 & Singapore & 0.845 & Singapore & 1.381 \\
\hline 4 & Estonia & 1 & Malaysia & 27.659 & Azerbaijan & 0.987 & Indonesia & 1 & Kyrgyz & 0.529 & Poland & 0.639 & Poland & 1.097 \\
\hline 5 & Greece & 1 & Poland & 27.659 & Turkmenistan & 0.987 & Malaysia & 1 & Belarus & 0.527 & $\begin{array}{l}\text { United Arab } \\
\text { Emirates }\end{array}$ & 0.602 & $\begin{array}{l}\text { United Arab } \\
\text { Emirates }\end{array}$ & 1.043 \\
\hline 64 & Yemen & 0.650 & Iraq & 0.083 & Malaysia & 0.805 & Tajikistan & 0.583 & $\begin{array}{c}\text { Brunei } \\
\text { Darussalam }\end{array}$ & 0.005 & $\begin{array}{c}\text { Brunei } \\
\text { Darussalam }\end{array}$ & 0.002 & $\begin{array}{c}\text { Brunei } \\
\text { Darussalam }\end{array}$ & 0.007 \\
\hline 65 & $\begin{array}{c}\text { Brunei } \\
\text { Darussalam }\end{array}$ & 0.637 & Syria & 0.056 & Poland & 0.805 & $\begin{array}{c}\text { Brunei } \\
\text { Darussalam }\end{array}$ & 0.545 & Nepal & 0.004 & Nepal & 0.000 & Nepal & 0.004 \\
\hline 66 & Bhutan & 0.570 & Bhutan & 0.038 & Turkey & 0.805 & Bhutan & 0.353 & Bhutan & 0.000 & Bhutan & 0.000 & Bhutan & 0.000 \\
\hline
\end{tabular}

Note: There is no parallel ranking result. In the case where multiple countries receive the same score, the rankings are sorted alphabetically. 


\subsection{Environmental Impacts of the OBOR Trade Network}

The level of national income has a certain impact on a country's import and export trade. In addition, a higher national income of a country usually dictates a more restricted environmental quality. Therefore, according to the World Bank's standard for grouping countries by per capita gross national income in 2016, the 66 countries of the OBOR trade network are divided into two groups: high- and low-income countries. Countries with GNI per capita greater than or equal to US\$4036 are high-income countries, and those with GNI per capita less than US $\$ 4036$ are low-income countries. In addition, as discussed Section 2 (cf. [9]), the structure of the trade network and the volume of trade have an impact on a country's carbon emissions.

Figure 2 shows the country-specific information obtained by averaging $\mathrm{CO} 2$ per capita emissions and trade and network indicators over the time period 2005-2014. Closeness centrality and eigenvector centrality are negatively correlated with $\mathrm{CO} 2$ emissions, while import/export amount, node strength, weighted indegree, weighted outdegree and clustering coefficient are positively proportional to $\mathrm{CO} 2$ emissions. On the other hand, the relationship between betweenness centrality and CO2 emissions is not clear enough. Overall, the correlation between the indicators of high-income countries and CO2 emissions is clear, and the per capita carbon emissions of high-income countries are significantly higher than those of low-income countries.
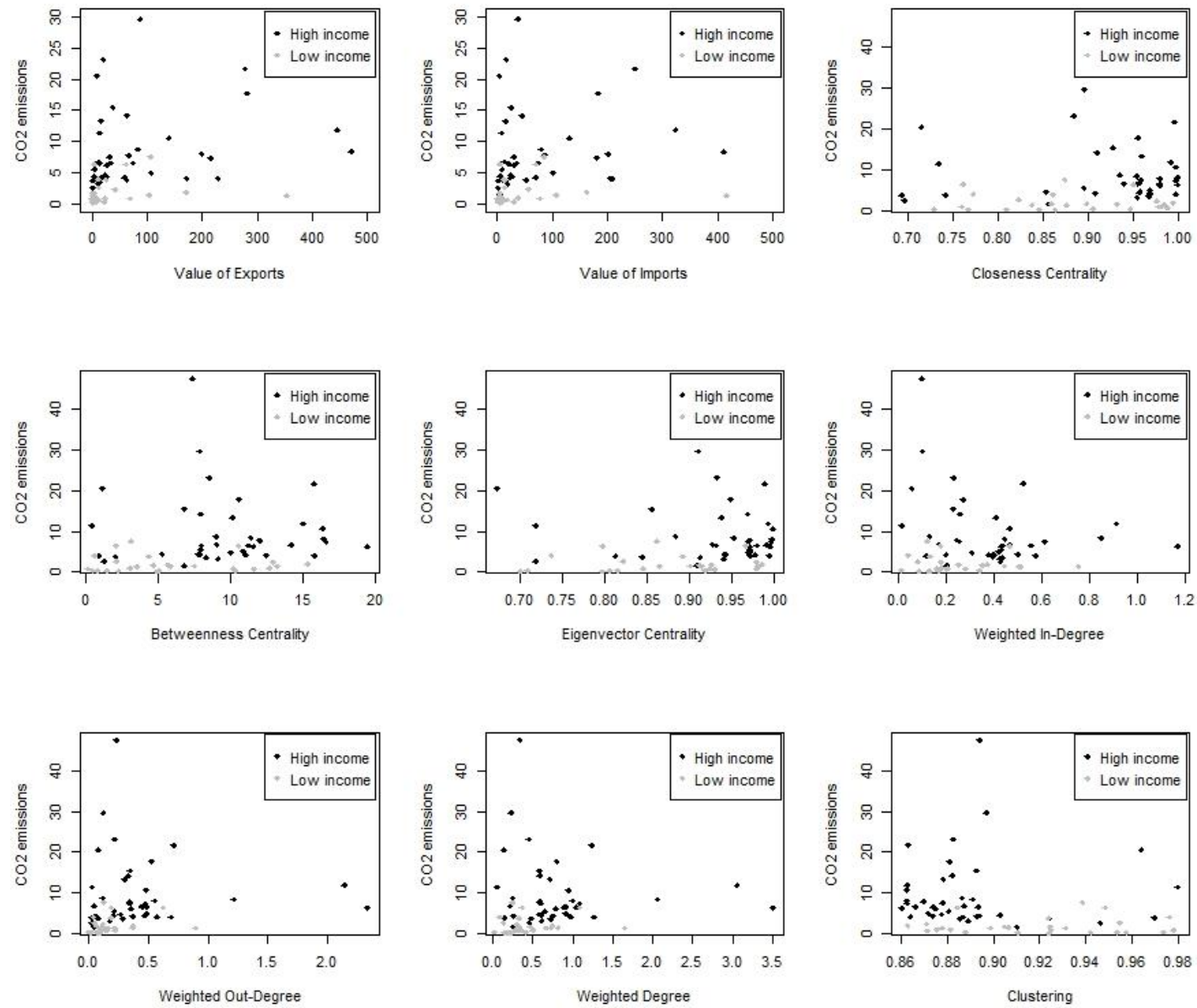

Figure 2. $\mathrm{CO} 2$ emissions, trade, and network statistical indicators by country. Note: We have calculated the average $\mathrm{CO} 2$ emissions per capita and the average network statistical indicators across the years in the sample: 2005-2014.

Time-specific information obtained by averaging $\mathrm{CO} 2$ per capita emissions and trade and network indicators across countries is shown in Figure 3. The results indicate that there is a positive correlation between trade volume and $\mathrm{CO} 2$ emissions. Similar positive correlations exist between emissions 
and eigenvector centrality, closeness centrality, and clustering coefficient, although these indicators have different ranges of variation, and $\mathrm{CO} 2$ emissions fluctuate more widely than the indicators. The betweenness centrality is consistent with the overall trend of $\mathrm{CO} 2$ emissions.
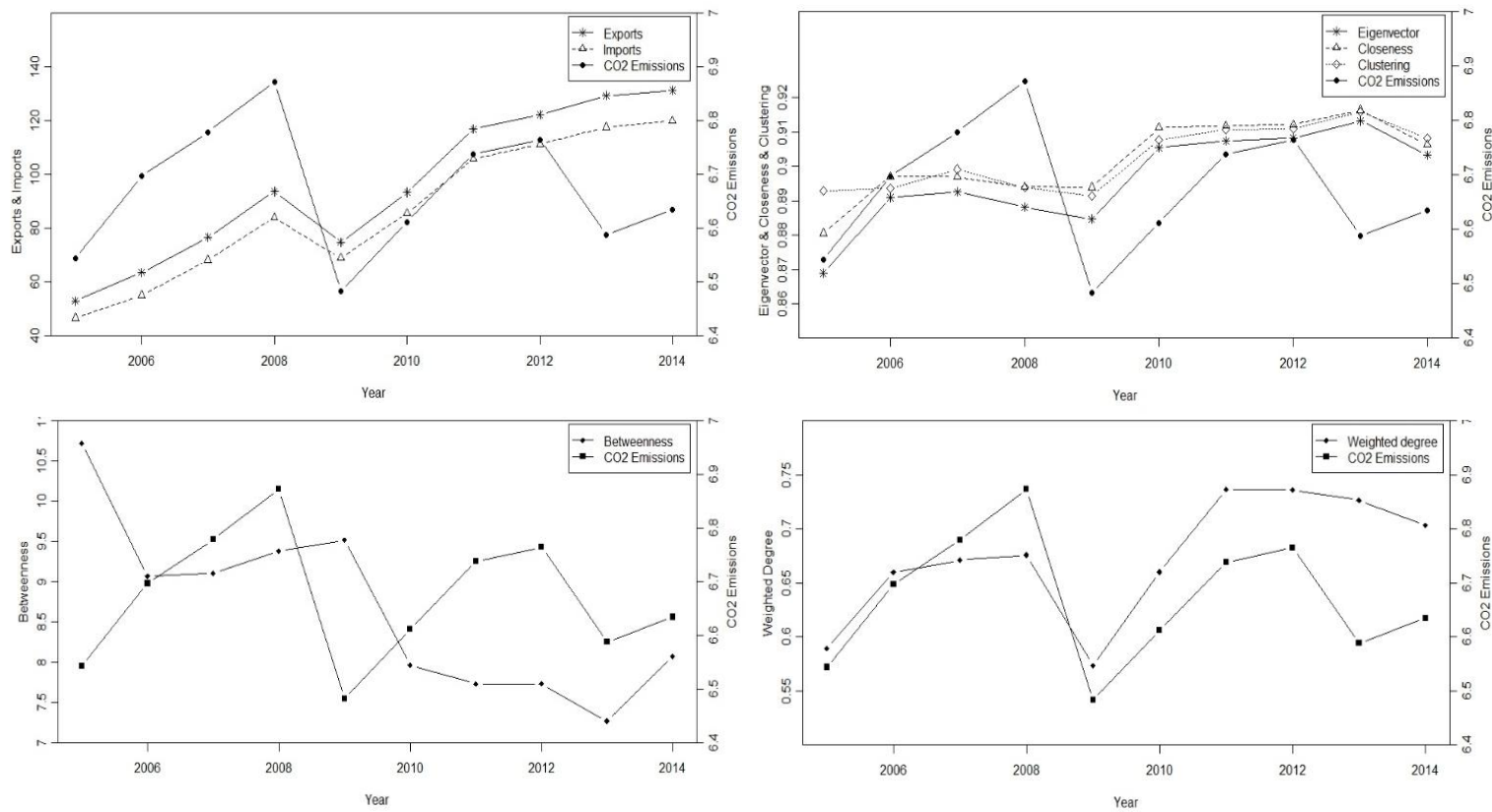

Figure 3. $\mathrm{CO} 2$ emissions, trade, and network indicators by year. Note: We have calculated the average $\mathrm{CO} 2$ emissions per capita and the average network indicators across countries obtained in the sample: 2005-2014.

Furthermore, we use the Spearman rank-order method to analyze the correlation between pairs of main variables with the panel data from 2005-2016. The results present a significantly positive relationship between $\mathrm{CO} 2$ emissions and most network indicators, except clustering, which is negatively correlated with $\mathrm{CO} 2$ emissions (see Table 4). In addition, imports and exports are both positively correlated with $\mathrm{CO} 2$ emissions.

Table 4. The correlation matrix of related variables.

\begin{tabular}{|c|c|c|c|c|c|c|c|c|}
\hline Variables & $\mathrm{CO} 2$ & $\begin{array}{c}\text { Betweenness } \\
\text { Centrality }\end{array}$ & $\begin{array}{l}\text { Closeness } \\
\text { Centrality }\end{array}$ & Clustering & $\begin{array}{c}\text { Eigenvector } \\
\text { Centrality }\end{array}$ & $\begin{array}{l}\text { Weighted } \\
\text { Degree }\end{array}$ & Import & Export \\
\hline $\mathrm{CO} 2$ & 1.00 & & & & & & & \\
\hline $\begin{array}{l}\text { Betweenness } \\
\text { Centrality }\end{array}$ & $\begin{array}{l}0.26^{* * *} \\
(6.76)\end{array}$ & 1.00 & & & & & & \\
\hline $\begin{array}{l}\text { Closeness } \\
\text { Centrality }\end{array}$ & $\begin{array}{l}0.26^{* * *} \\
(6.77)\end{array}$ & $\begin{array}{l}0.70^{* * *} \\
(25.21)\end{array}$ & 1.00 & & & & & \\
\hline Clustering & $\begin{array}{c}-0.33^{* * *} \\
(-8.76) \\
\end{array}$ & $\begin{array}{l}-0.81^{* * *} \\
(-35.14) \\
\end{array}$ & $\begin{array}{l}-0.77^{* * *} \\
(-31.09) \\
\end{array}$ & 1.00 & & & & \\
\hline $\begin{array}{l}\text { Eigenvector } \\
\text { Centrality }\end{array}$ & $\begin{array}{l}0.35^{* * *} \\
(9.64)\end{array}$ & $\begin{array}{l}0.71^{* * *} \\
(25.56)\end{array}$ & $\begin{array}{l}0.79^{* * *} \\
(32.61)\end{array}$ & $\begin{array}{l}-0.77^{* * *} \\
(-30.48)\end{array}$ & 1.00 & & & \\
\hline $\begin{array}{l}\text { Weighted } \\
\text { Degree }\end{array}$ & $\begin{array}{l}0.30^{* * *} \\
(7.92)\end{array}$ & $\begin{array}{l}0.49^{* * *} \\
(14.48)\end{array}$ & $\begin{array}{l}0.61^{* * *} \\
(19.80)\end{array}$ & $\begin{array}{l}-0.51^{* * *} \\
(-14.99)\end{array}$ & $\begin{array}{l}0.65^{* * *} \\
(21.64)\end{array}$ & 1.00 & & \\
\hline Import & $\begin{array}{l}0.44^{* * *} \\
(12.40)\end{array}$ & $\begin{array}{l}0.62^{* * *} \\
(20.29)\end{array}$ & $\begin{array}{l}0.80^{* * *} \\
(34.07)\end{array}$ & $\begin{array}{l}-0.63^{* * *} \\
(-20.59)\end{array}$ & $\begin{array}{l}0.72^{* * *} \\
(26.64)\end{array}$ & $\begin{array}{l}0.62^{* * *} \\
(20.24)\end{array}$ & 1.00 & \\
\hline Export & $\begin{array}{l}0.54^{* * *} \\
(16.15)\end{array}$ & $\begin{array}{l}0.58^{* * *} \\
(18.12)\end{array}$ & $\begin{array}{l}0.74^{* * *} \\
(28.21)\end{array}$ & $\begin{array}{l}-0.58^{* * *} \\
(-18.35)\end{array}$ & $\begin{array}{l}0.67^{* * *} \\
(22.69)\end{array}$ & $\begin{array}{l}0.59^{* * *} \\
(18.62)\end{array}$ & $\begin{array}{l}0.98^{* * *} \\
(112.91)\end{array}$ & 1.00 \\
\hline
\end{tabular}




\section{The Environmental Effect Analysis}

The recent significant increase in trade flows among developed and developing countries has further promoted the integration and globalization of international markets. We have witnessed a positive impact of globalization on world economic growth through the promotion of each country's competitive advantages and the increased flow of resources and products across countries. In addition, the increase in trade flows may have a negative impact on the environment. According to the existing literature, trade affects the environment mainly through three different channels: scale effect, composition effect and technology effect [21]. The scale effect indicates that the increase in GDP leads to higher pollution; the composition effect refers to changes in a country's sectoral composition due to trade, which may have a positive or negative impact on the country's environmental situation; and the technological effect indicates that trade has a positive impact on the environment through the use of clean production technology. In trade networks, core country nodes usually have strong market bargaining power in trade negotiations. They often have many opportunities to reduce CO2 emissions by sacrificing the less-dominant countries. The trade network topology reflects the trade links among country nodes and the impact of these links on the trade relations with other trading partners. As discussed in the introduction, we believe that the topology of the OBOR trade network reflects the characteristics of the trade system and, therefore, impacts $\mathrm{CO} 2$ emissions and reflects the indirect effects of trade on the environment. Moreover, the volume of import and export among the countries reflects the direct effects of trade on the environment.

\subsection{Model and Data Description}

Our aim is to investigate the environmental effects of the OBOR trade network through the direct and indirect effects of trade. Similar to the work of [9] (although we include more network structure variables), the following multiple regression models are established and estimated by panel data. To eliminate potential heteroscedasticity, we take the logarithm for all variables from 2005 to 2014. The hyperbolic transformation is used to deal with the 0 values for network characteristic indicators. The data for all variables except the network characteristic indicators are obtained from the World Development Indicators database. Then, after introducing control variables, the environmental estimation model can be written as follows:

$$
\begin{gathered}
L N C_{i t}=\lambda_{i}+\gamma_{t}+\alpha L N Z_{i t}+\beta_{1} L N G D P_{i t}+\beta_{2} L_{N I n d u s t r y}+\beta_{3} L N F D I_{i t}+\beta_{4} L N G D P 2_{i t}+\varepsilon_{i t} \\
L N C_{i t}=\lambda_{i}+\gamma_{t}+\alpha L N Z_{i t}+\theta_{1} \text { LNTrade }_{i t}+\theta_{2} L N G D P_{i t}+\theta_{3} L_{N N \text { Industry }}+\theta_{4} L_{N N D I_{i t}}+\theta_{5} L N G D P 2_{i t}+\varepsilon_{i t}
\end{gathered}
$$

where $i$ denotes countries, $t$ denotes years, $\lambda_{i}$ denotes country fixed effects, $\gamma_{t}$ denotes time fixed effects, and $\varepsilon_{i t}$ denotes the random interference term that obeys the standard distribution. In Formulas (6) and (7), $C$ denotes $\mathrm{CO} 2$ emissions and is measured by per capita emissions. $Z_{i t}$ denotes any of the statistical indicators of the OBOR trade network of country $i$ in year $t$ as described in Section 2.2, including Betweenness, Eigenvector, Clustering, Weighted indegree and Weighted outdegree. The model includes each of the network indicators to investigate the indirect effects of trade on the environment. Trade is a country's total amount of imports and exports and is used to examine the direct effects of trade on the environment. The following four indicators are introduced as control variables: GDP reflects the scale effect, measured by per capita GDP; Industry measures the composition effect, measured by the share of industry added value in GDP. Since FDI is an important means of technology transfer and knowledge spillover across countries, FDI is used to capture the technology effect and is measured by net inflows of FDI (as a percentage of GDP). The variable GDP2 takes the square of per capita GDP to test whether the environmental Kuznets curve [22] is observed in the OBOR trade network.

Descriptive statistics are reported in Table 5. We observe that, on average, the $\mathrm{CO} 2$ emissions in high-income countries are significantly higher than those in low-income countries, which means that high-income countries pollute more. The high-income countries have better economic status, and the 
weights of FDI and industrial added value are slightly larger. Furthermore, the high-income countries have larger trade volumes and more centrality in the OBOR trade network.

Table 5. Descriptive statistics.

\begin{tabular}{ccccccccc}
\hline \multirow{2}{*}{ Variables } & \multicolumn{3}{c}{ High Income (390 obs.) } & \multicolumn{3}{c}{ Low Income (260 obs.) } \\
\cline { 2 - 9 } & Mean & Std. Dev & Min & Max & Mean & Std. Dev & Min & Max \\
\hline LNC & 8.911 & 0.720 & 7.172 & 11.048 & 7.016 & 1.115 & 3.969 & 9.511 \\
LNCloseness & 4.765 & 0.111 & 4.175 & 4.852 & 4.708 & 0.121 & 4.326 & 4.852 \\
LNBetweenness & 2.504 & 1.162 & 0 & 4.700 & 1.899 & 1.190 & 0.000 & 3.717 \\
LNEigenvector & 0.829 & 0.077 & 0 & 0.881 & 0.764 & 0.120 & 0.311 & 0.881 \\
LNClustering & 0.802 & 0.024 & 0.746 & 0.881 & 0.823 & 0.029 & 0.766 & 0.875 \\
LNWindegree & 0.370 & 0.213 & 0 & 1.284 & 0.251 & 0.189 & 0.000 & 0.882 \\
LNWoutdegree & 0.384 & 0.350 & 0.002 & 1.768 & 0.180 & 0.202 & 0.000 & 1.044 \\
LNFDI & 1.361 & 1.081 & -3.036 & 5.290 & 0.936 & 1.178 & -4.837 & 3.782 \\
LNIndustry & 3.512 & 0.419 & 2.372 & 4.779 & 3.431 & 0.325 & 2.737 & 4.252 \\
LNTrade & 4.400 & 1.503 & 0.601 & 8.473 & 3.070 & 1.864 & -3.416 & 6.927 \\
LNGDP & 9.361 & 0.844 & 7.441 & 11.391 & 7.300 & 0.750 & 5.510 & 8.974 \\
LNGDP2 & 88.338 & 15.930 & 55.369 & 129.766 & 53.849 & 10.992 & 30.364 & 80.524 \\
\hline
\end{tabular}

\subsection{Empirical Analysis}

\subsubsection{The Unit Root Test of the Panel Data}

A unit root test is needed to determine the stationarity of panel data to avoid the spurious regression problem. In this paper, the Levin-Lin-Chu (LLC) [23] and Fisher-ADF [24,25] tests are used to test the unit root of the model variables. The results exhibit stationary behavior in all variables' first differences at the $1 \%$ significance level and follow the I(1) process, indicating suitability for panel regression analysis.

\subsubsection{Empirical Results}

To avoid possible endogeneity problems, three-stage least squares (3SLS) is used to examine the relationship between $\mathrm{CO} 2$ emissions and OBOR trade network characteristics. Because of the endogeneity of trade and network statistical indicators, we simultaneously estimate income, trade, network and environmental equations using a 3SLS procedure. These equations are as follows:

$$
\begin{aligned}
& L N G D P_{i t}=\text { Intercept }+\omega_{1} L \cdot L N G D P(-1)_{i t}+\omega_{2} \text { pop }_{i t}+\omega_{3} \text { LNinvestment }_{i t} \\
& +\omega_{4} \text { Country }_{i}+\omega_{5} \text { Year }_{t}+\varepsilon_{i t} \\
& \text { LNTrade }_{i t}=\text { Intercept }+\rho_{1} L N G D P_{i t}+\rho_{2} \text { pop }_{i t}+\rho_{3} \text { land }_{i t}+\rho_{4} L N Z_{i t} \\
& +\rho_{5} \text { Tpop }_{1 t}+\rho_{6} \text { Tpop }_{i t}+\rho_{7} \text { Country }_{i}+\rho_{8} \text { Year }_{t}+\varepsilon_{i t} \\
& L N Z_{i t}=\text { Intercept }+\tau_{1} L N G D P_{i t}+\tau_{2} \text { pop }_{i t}+\tau_{3} \text { land }_{i t}+\tau_{4} L N G N I_{i t}+\tau_{5} L N T \text { rade }_{i t} \\
& +\tau_{6} \text { Tpop }_{i t}+\tau_{7} \text { Tpop }_{2 i t}+\tau_{8} \text { Country }_{i}+\tau_{9} \text { Year }_{t}+\varepsilon_{i t} \\
& L N C_{i t}=\text { Intercept }+\zeta_{1} L N Z_{i t}+\zeta_{2} L N F D I_{i t}+\zeta_{3} L N I n d u s t r y_{i t}+\zeta_{4} L_{N T r a d e} i t \\
& +\zeta_{5} L_{N G D P_{i t}}+\zeta_{6} L_{N N G D P 2_{i t}}+\zeta_{7} \text { Country }_{i}+\zeta_{8} \text { Year }_{t}+\varepsilon_{i t}
\end{aligned}
$$

In the income equation (see Equation (8)), we regress per capita GDP on lagged per capita GDP, population, gross capital formation of GDP, country dummies and year dummies. The trade equation (see Equation (9)) is regressed on per capita GDP, population, land area, network statistical indicator, trade partners' population, trade partners' partners' population, country dummies and year dummies. Similar to the trade equation, in the network equation (see Equation (10)), the dependent variable is a network statistical indicator and the independent variables are per capita GDP, population, land area, per capita GNI, trade volume, trade partners' population, trade partners' partners' population, country 
dummies and year dummies. In the environmental equation (see Equation (11)), we regress per capita $\mathrm{CO} 2$ emissions on network statistical indicator, net inflows of FDI (as a percentage of GDP), the share of industry added value in GDP, trade volume, per capita GDP, per capita GDP square, country dummies and year dummies. Trade partners' population and trade partners' partners' population are the instrumental variables used to obtain exogenous variation in trade and network equations. The income, trade, and network equations are jointly estimated, together with the environmental estimation model using a 3SLS procedure.

Tables 6-8 provide the analysis of the relationship between $\mathrm{CO} 2$ emissions and the OBOR trade network characteristics for all countries, high-income countries, and low-income countries, respectively. The estimated results contain 65 countries; the State of Palestine is deleted because of too much missing data. We present the results of the environmental equation with a 3SLS to illustrate the simultaneity between income, trade, network and per capita $\mathrm{CO} 2$ emissions. The results reveal certain differences between the three categories in terms of the relationships between characteristics of the OBOR trade network structure and $\mathrm{CO} 2$ emissions.

Tables 6-8 show the estimation results for an all-country sample, high-income country sample, and low-income country sample, respectively. In each table, column 1, 3, 5, 7, 9, and 11 show the impacts of respective network indicators on $\mathrm{CO} 2$ emission. The rest of the columns in each table show the same type of impacts, but with additional total trade volume ( $L n T r a d e$ ) variables, to examine the changes in environmental quality caused by the direct trade effect.

The first two columns of Tables 6-8 show the estimation relationship of the closeness centrality (LNCloseness) of the OBOR trade network with per capita CO2 with and without trade volume, respectively. The results are significant for the high-income country sample while it is not the case for the other two samples. Furthermore, for the high-income country sample, the sign of the coefficients of LNCloseness is consistent with the result of [9]. However, after adding the total trade volume (LNTrade), the $\mathrm{CO} 2$ emissions are positively and significantly affected by the closeness centrality (LNCloseness), which is contrary to the result of [9] (see column 2 of Table 7). Our explanation of this result is that the closer the relationship between countries and their trade partners, the higher their $\mathrm{CO} 2$ emissions. In high-income countries, usually with relatively abundant capital, trade liberalization leads to the expansion of capital intensive industries. As the carbon intensity of capital intensive industry is higher than that of labor-intensive industry, being closer to trade partners will increase the domestic $\mathrm{CO} 2$ emissions in high-income countries.

In the third column of Tables 6-8, it shows that betweenness centrality (LNBetweenness) has a significant positive effect on $\mathrm{CO} 2$ emissions for the sample of high-income countries, while it decreases $\mathrm{CO} 2$ emissions for the sample of low-income countries, which is consistent with the result of [9]. In addition, after introducing LNTrade into the analysis (see the forth columns), betweenness has an impact similar to that found in the research of [9] and for the low-income countries, it has larger negative impact on $\mathrm{CO} 2$ emissions. This indicates that the stronger the "intermediary" role of trade in low-income countries is, the less the $\mathrm{CO} 2$ emissions in these countries will be. The important role low-income countries played in the participation of the transshipment trade is beneficial for improving their bargaining power in trade negotiations, which can help these countries to obtain environmentally friendly goods. 
Table 6. Estimation result 1 (all-country sample).

\begin{tabular}{|c|c|c|c|c|c|c|c|c|c|c|c|c|}
\hline & (1)3SLS & (2)3SLS & (3)3SLS & (4)3SLS & (5)3SLS & (6)3SLS & (7)3SLS & (8)3SLS & (9)3SLS & (10)3SLS & (11)3SLS & (12)3SLS \\
\hline LNCloseness & $\begin{array}{c}0.944 \\
(1.223)\end{array}$ & $\begin{array}{c}0.486 \\
(1.303)\end{array}$ & & & & & & & & & & \\
\hline LNBetweenness & & & $\begin{array}{c}0.027 \\
(0.137)\end{array}$ & $\begin{array}{c}-0.769^{* *} \\
(0.308)\end{array}$ & & & & & & & & \\
\hline LNEigenvector & & & & & $\begin{array}{c}3.402^{* * *} \\
(1.267)\end{array}$ & $\begin{array}{c}1.015 \\
(1.744)\end{array}$ & & & & & & \\
\hline LNClustering & & & & & & & $\begin{array}{c}2.062 \\
(3.653)\end{array}$ & $\begin{array}{l}13.592^{*} \\
(7.929)\end{array}$ & & & & \\
\hline LNWindegree & & & & & & & & & $\begin{array}{c}0.8 \\
(0.574)\end{array}$ & $\begin{array}{c}0.109 \\
(0.643)\end{array}$ & & \\
\hline LNWoutdegree & & & & & & & & & & & $\begin{array}{l}1.004^{*} \\
(0.555)\end{array}$ & $\begin{array}{c}1.351 \\
(0.854)\end{array}$ \\
\hline LNTrade & & $\begin{array}{c}0.054^{* * *} \\
(0.008)\end{array}$ & & $\begin{array}{c}0.409^{* * *} \\
(0.135)\end{array}$ & & $\begin{array}{c}0.191 \\
(0.136)\end{array}$ & & $\begin{array}{c}-0.016^{* * *} \\
(0.236)\end{array}$ & & $\begin{array}{c}0.099^{* * *} \\
(0.125)\end{array}$ & & $\begin{array}{l}0.480^{* *} \\
(0.026)\end{array}$ \\
\hline LNFDI & $\begin{array}{c}0.025^{* * *} \\
(0.009)\end{array}$ & $\begin{array}{l}0.019^{*} \\
(0.010)\end{array}$ & $\begin{array}{l}0.025^{* *} \\
(0.010)\end{array}$ & $\begin{array}{l}0.027^{* *} \\
(0.013)\end{array}$ & $\begin{array}{l}0.019^{*} \\
(0.010)\end{array}$ & $\begin{array}{l}0.022^{* *} \\
(0.010)\end{array}$ & $\begin{array}{c}0.025^{* * *} \\
(0.009)\end{array}$ & $\begin{array}{l}0.018^{*} \\
(0.010)\end{array}$ & $\begin{array}{l}0.024^{* *} \\
(0.010)\end{array}$ & $\begin{array}{l}0.018^{*} \\
(0.010)\end{array}$ & $\begin{array}{l}0.024^{* *} \\
(0.010)\end{array}$ & $\begin{array}{l}0.019^{*} \\
(0.010)\end{array}$ \\
\hline LNIndustry & $\begin{array}{c}-0.153^{* *} \\
(0.064)\end{array}$ & $\begin{array}{c}-0.356^{* * *} \\
(0.124)\end{array}$ & $\begin{array}{c}-0.165^{* *} \\
(0.080)\end{array}$ & $\begin{array}{c}-0.268^{* *} \\
(0.134)\end{array}$ & $\begin{array}{c}-0.237^{* * *} \\
(0.076)\end{array}$ & $\begin{array}{c}-0.352^{* * *} \\
(0.125)\end{array}$ & $\begin{array}{c}-0.149^{* *} \\
(0.068)\end{array}$ & $\begin{array}{c}-0.380^{*} \\
(0.194)\end{array}$ & $\begin{array}{c}-0.186^{* *} \\
(0.083)\end{array}$ & $\begin{array}{c}-0.396^{* * *} \\
(0.127)\end{array}$ & $\begin{array}{c}-0.169^{* *} \\
(0.077)\end{array}$ & $\begin{array}{l}-0.349 \\
(0.241)\end{array}$ \\
\hline LNGDP & $\begin{array}{c}0.828^{* * *} \\
(0.234)\end{array}$ & $\begin{array}{c}0.645^{* * *} \\
(0.219)\end{array}$ & $\begin{array}{c}2.009 \\
(0.215)\end{array}$ & $\begin{array}{l}-0.024 \\
(0.221)\end{array}$ & $\begin{array}{c}0.937^{* * *} \\
(0.211)\end{array}$ & $\begin{array}{c}0.417 \\
(0.245)\end{array}$ & $\begin{array}{c}-0.064^{*} \\
(0.034)\end{array}$ & $\begin{array}{l}0.455^{* *} \\
(0.551)\end{array}$ & $\begin{array}{c}0.095 \\
(0.214)\end{array}$ & $\begin{array}{c}0.969^{* * *} \\
(0.047)\end{array}$ & $\begin{array}{c}0.950^{* * *} \\
(0.228)\end{array}$ & $\begin{array}{c}0.336 \\
(0.246)\end{array}$ \\
\hline LNGDP2 & $\begin{array}{l}-0.027^{*} \\
(0.014)\end{array}$ & $\begin{array}{l}-0.002 \\
(0.019) \\
\end{array}$ & $\begin{array}{c}-0.029^{* *} \\
(0.013)\end{array}$ & $\begin{array}{l}-0.015 \\
(0.018) \\
\end{array}$ & $\begin{array}{c}-0.039^{* * *} \\
(0.013)\end{array}$ & $\begin{array}{l}-0.013 \\
(0.019) \\
\end{array}$ & $\begin{array}{c}-0.027^{* *} \\
(0.013)\end{array}$ & $\begin{array}{l}-0.015 \\
(0.026) \\
\end{array}$ & $\begin{array}{c}-0.032^{* *} \\
(0.014)\end{array}$ & $\begin{array}{l}-0.005 \\
(0.017) \\
\end{array}$ & $\begin{array}{c}-0.033^{* *} \\
(0.013)\end{array}$ & $\begin{array}{l}-0.024 \\
(0.025) \\
\end{array}$ \\
\hline Observations & 558 & 556 & 558 & 556 & 558 & 556 & 558 & 556 & 558 & 556 & 558 & 556 \\
\hline Country FE & YES & YES & YES & YES & YES & YES & YES & YES & YES & YES & YES & YES \\
\hline Year FE & YES & YES & YES & YES & YES & YES & YES & YES & YES & YES & YES & YES \\
\hline Wald F-statistic & 7.29 & 8.808 & 1.722 & 2.319 & 7.08 & 9.276 & 5.33 & 5.934 & 1.28 & 1.244 & 4.22 & 4.013 \\
\hline Hansen J test (p-value) & 0.2345 & 0.2123 & 0.3851 & 0.3001 & 0.1673 & 0.1731 & 0.3472 & 0.2936 & 0.2332 & 0.2327 & 0.4058 & 0.3922 \\
\hline R-squared & 0.9885 & 0.9834 & 0.9886 & 0.9256 & 0.9837 & 0.9855 & 0.9883 & 0.9637 & 0.9877 & 0.9844 & 0.9853 & 0.9669 \\
\hline
\end{tabular}

Note: (1) The Wald F statistic is a joint significance test of the instruments. The Hansen J (p-value) is a test of overidentification restrictions in the network equation. (2) * $p<0.1$; ** $p<0.05$;

$* * * \mathrm{p}<0.1$. (3) Robust standard errors in parenthesis. 
Table 7. Estimation result 2 (high-income country sample).

\begin{tabular}{|c|c|c|c|c|c|c|c|c|c|c|c|c|}
\hline & (1)3SLS & (2)3SLS & (3)3SLS & (4)3SLS & (5)3SLS & (6)3SLS & (7)3SLS & (8)3SLS & (9)3SLS & (10)3SLS & (11)3SLS & (12)3SLS \\
\hline LNCloseness & $\begin{array}{c}0.557 \\
(1.032)\end{array}$ & $\begin{array}{l}2.489^{*} \\
(1.484)\end{array}$ & & & & & & & & & & \\
\hline LNBetweenness & & & $\begin{array}{c}0.360^{* * *} \\
(0.081)\end{array}$ & $\begin{array}{c}0.13 \\
(0.120)\end{array}$ & & & & & & & & \\
\hline LNEigenvector & & & & & $\begin{array}{c}3.078^{* * *} \\
(0.985)\end{array}$ & $\begin{array}{c}1.596 \\
(1.246)\end{array}$ & & & & & & \\
\hline LNClustering & & & & & & & $\begin{array}{c}-9.296^{* * *} \\
(3.530)\end{array}$ & $\begin{array}{l}-3.612 \\
(3.974)\end{array}$ & & & & \\
\hline LNWindegree & & & & & & & & & $\begin{array}{c}1.607^{* * *} \\
(0.484)\end{array}$ & $\begin{array}{c}0.585 \\
(0.648)\end{array}$ & & \\
\hline LNWoutdegree & & & & & & & & & & & $\begin{array}{l}0.628^{* *} \\
(0.268)\end{array}$ & $\begin{array}{c}0.07 \\
(0.302)\end{array}$ \\
\hline LNTrade & & $\begin{array}{c}1.018^{* * *} \\
(0.201)\end{array}$ & & $\begin{array}{c}0.650^{* * *} \\
(0.053)\end{array}$ & & $\begin{array}{c}0.694^{* * *} \\
(0.194)\end{array}$ & & $\begin{array}{c}-0.041^{* * *} \\
(0.004)\end{array}$ & & $\begin{array}{c}0.280^{* * *} \\
(0.239)\end{array}$ & & $\begin{array}{c}0.148 \\
(0.094)\end{array}$ \\
\hline LNFDI & $\begin{array}{l}0.020^{* *} \\
(0.008)\end{array}$ & $\begin{array}{c}0.008 \\
(0.009)\end{array}$ & $\begin{array}{c}0.012 \\
(0.009)\end{array}$ & $\begin{array}{c}0.01 \\
(0.009)\end{array}$ & $\begin{array}{c}0.012 \\
(0.009)\end{array}$ & $\begin{array}{c}0.01 \\
(0.010)\end{array}$ & $\begin{array}{l}0.015^{*} \\
(0.009)\end{array}$ & $\begin{array}{c}0.011 \\
(0.009)\end{array}$ & $\begin{array}{l}0.014^{*} \\
(0.008)\end{array}$ & $\begin{array}{c}0.013 \\
(0.009)\end{array}$ & $\begin{array}{l}0.018^{* *} \\
(0.008)\end{array}$ & $\begin{array}{c}0.011 \\
(0.009)\end{array}$ \\
\hline LNIndustry & $\begin{array}{c}0.025 \\
(0.059)\end{array}$ & $\begin{array}{c}-0.314^{* * *} \\
(0.096)\end{array}$ & $\begin{array}{c}-0.114 \\
(0.073)\end{array}$ & $\begin{array}{c}-0.287^{* * *} \\
(0.101)\end{array}$ & $\begin{array}{c}-0.1 \\
(0.072)\end{array}$ & $\begin{array}{c}-0.315^{* * *} \\
(0.109)\end{array}$ & $\begin{array}{l}-0.061 \\
(0.068)\end{array}$ & $\begin{array}{c}-0.269^{* * *} \\
(0.093)\end{array}$ & $\begin{array}{l}-0.061 \\
(0.076)\end{array}$ & $\begin{array}{c}-0.225^{* *} \\
(0.091)\end{array}$ & $\begin{array}{c}0.019 \\
(0.059)\end{array}$ & $\begin{array}{c}-0.240^{* * *} \\
(0.091)\end{array}$ \\
\hline LNGDP & $\begin{array}{c}0.248 \\
(0.436)\end{array}$ & $\begin{array}{l}0.051^{* *} \\
(0.572)\end{array}$ & $\begin{array}{l}1.110^{* *} \\
(0.549)\end{array}$ & $\begin{array}{l}1.441^{* *} \\
(0.613)\end{array}$ & $\begin{array}{l}1.089^{*} \\
(0.084)\end{array}$ & $\begin{array}{l}1.521^{* *} \\
(0.667)\end{array}$ & $\begin{array}{c}-0.095^{* * *} \\
(0.505)\end{array}$ & $\begin{array}{c}0.314^{* * *} \\
(0.568)\end{array}$ & $\begin{array}{c}0.665^{* * *} \\
(0.186)\end{array}$ & $\begin{array}{c}-0.221^{*} \\
(0.126)\end{array}$ & $\begin{array}{l}0.369^{*} \\
(0.209)\end{array}$ & $\begin{array}{l}1.029^{*} \\
(0.075)\end{array}$ \\
\hline LNGDP2 & $\begin{array}{c}0.01 \\
(0.024)\end{array}$ & $\begin{array}{c}-0.089^{* *} \\
(0.035)\end{array}$ & $\begin{array}{l}-0.041 \\
(0.031)\end{array}$ & $\begin{array}{c}-0.079^{* *} \\
(0.036)\end{array}$ & $\begin{array}{l}-0.038 \\
(0.032)\end{array}$ & $\begin{array}{c}-0.084^{* *} \\
(0.040)\end{array}$ & $\begin{array}{l}-0.021 \\
(0.028)\end{array}$ & $\begin{array}{c}-0.072^{* *} \\
(0.034)\end{array}$ & $\begin{array}{l}-0.003 \\
(0.027)\end{array}$ & $\begin{array}{l}-0.048 \\
(0.039)\end{array}$ & $\begin{array}{c}0.022 \\
(0.025)\end{array}$ & $\begin{array}{c}-0.064^{*} \\
(0.033)\end{array}$ \\
\hline Observations & 337 & 335 & 337 & 335 & 337 & 335 & 337 & 335 & 337 & 335 & 337 & 335 \\
\hline Country FE & YES & YES & YES & YES & YES & YES & YES & YES & YES & YES & YES & YES \\
\hline Year FE & YES & YES & YES & YES & YES & YES & YES & YES & YES & YES & YES & YES \\
\hline Wald F-statistic & 10.952 & 13.925 & 4.358 & 7.178 & 13.131 & 18.897 & 8.531 & 10.636 & 5.143 & 4.796 & 28.527 & 24.942 \\
\hline Hansen J test ( $\mathrm{p}$-value) & 0.0933 & 0.0755 & 0.1637 & 0.0937 & 0.0978 & 0.0826 & 0.2113 & 0.1253 & 0.6885 & 0.4783 & 0.6199 & 0.5641 \\
\hline R-squared & 0.9807 & 0.9571 & 0.951 & 0.97 & 0.9725 & 0.9698 & 0.9712 & 0.9723 & 0.9699 & 0.9737 & 0.9771 & 0.9658 \\
\hline
\end{tabular}

Note: (1) The Wald F statistic is a joint significance test of the instruments. The Hansen J ( $\mathrm{p}$-value) is a test of overidentification restrictions in the network equation. (2) * $\mathrm{p}<0.1$; ** $\mathrm{p}<0.05$;

*** $\mathrm{p}<0.1$. (3) Robust standard errors in parenthesis. 
Table 8. Estimation result 3 (low-income country sample).

\begin{tabular}{|c|c|c|c|c|c|c|c|c|c|c|c|c|}
\hline & (1)3SLS & (2)3SLS & (3)3SLS & (4)3SLS & (5)3SLS & (6)3SLS & (7)3SLS & (8)3SLS & (9)3SLS & (10)3SLS & (11)3SLS & (12)3SLS \\
\hline LNCloseness & $\begin{array}{c}1.853 \\
(2.293)\end{array}$ & $\begin{array}{c}2.634 \\
(2.432)\end{array}$ & & & & & & & & & & \\
\hline LNBetweenness & & & $\begin{array}{c}-0.345^{* * *} \\
(0.109)\end{array}$ & $\begin{array}{c}-0.441^{* * *} \\
(0.112)\end{array}$ & & & & & & & & \\
\hline LNEigenvector & & & & & $\begin{array}{c}1.153 \\
(0.913)\end{array}$ & $\begin{array}{l}-0.214 \\
(1.082)\end{array}$ & & & & & & \\
\hline LNClustering & & & & & & & $\begin{array}{l}7.778^{*} \\
(4.280)\end{array}$ & $\begin{array}{c}18.233^{* * *} \\
(4.961)\end{array}$ & & & & \\
\hline LNWindegree & & & & & & & & & $\begin{array}{c}0.262 \\
(0.444)\end{array}$ & $\begin{array}{c}0.004 \\
(0.459)\end{array}$ & & \\
\hline LNWoutdegree & & & & & & & & & & & $\begin{array}{c}-0.903^{*} \\
(0.520)\end{array}$ & $\begin{array}{l}-0.471 \\
(0.571)\end{array}$ \\
\hline LNTrade & & $\begin{array}{c}0.037^{* * *} \\
(0.054)\end{array}$ & & $\begin{array}{c}0.581^{* * *} \\
(0.079)\end{array}$ & & $\begin{array}{l}0.145^{* *} \\
(0.060)\end{array}$ & & $\begin{array}{c}0.308^{* * *} \\
(0.002)\end{array}$ & & $\begin{array}{c}0.160^{* * *} \\
(0.052)\end{array}$ & & $\begin{array}{l}0.132 * * \\
(0.057)\end{array}$ \\
\hline LNFDI & $\begin{array}{l}0.035^{*} \\
(0.020)\end{array}$ & $\begin{array}{c}0.028 \\
(0.021)\end{array}$ & $\begin{array}{l}0.046^{* *} \\
(0.021)\end{array}$ & $\begin{array}{l}0.039^{*} \\
(0.021)\end{array}$ & $\begin{array}{l}0.035^{*} \\
(0.020)\end{array}$ & $\begin{array}{c}0.031 \\
(0.020)\end{array}$ & $\begin{array}{l}0.037^{*} \\
(0.020)\end{array}$ & $\begin{array}{c}0.03 \\
(0.019)\end{array}$ & $\begin{array}{l}0.037^{*} \\
(0.019)\end{array}$ & $\begin{array}{c}0.031 \\
(0.020)\end{array}$ & $\begin{array}{c}0.033 \\
(0.021)\end{array}$ & $\begin{array}{c}0.03 \\
(0.021)\end{array}$ \\
\hline LNIndustry & $\begin{array}{c}-0.407^{* * *} \\
(0.153)\end{array}$ & $\begin{array}{c}-0.613^{* * *} \\
(0.188)\end{array}$ & $\begin{array}{c}-0.499^{* * *} \\
(0.168)\end{array}$ & $\begin{array}{c}-0.758^{* * *} \\
(0.190)\end{array}$ & $\begin{array}{c}-0.391^{* *} \\
(0.153)\end{array}$ & $\begin{array}{c}-0.586^{* * *} \\
(0.193)\end{array}$ & $\begin{array}{c}-0.501^{* * *} \\
(0.160)\end{array}$ & $\begin{array}{c}-0.856^{* * *} \\
(0.199)\end{array}$ & $\begin{array}{c}-0.412^{* * *} \\
(0.153)\end{array}$ & $\begin{array}{c}-0.606^{* * *} \\
(0.182)\end{array}$ & $\begin{array}{c}-0.460^{* * *} \\
(0.156)\end{array}$ & $\begin{array}{c}-0.608^{* * *} \\
(0.191)\end{array}$ \\
\hline LNGDP & $\begin{array}{c}-0.337^{*} \\
(0.180)\end{array}$ & $\begin{array}{l}0.964^{* *} \\
(0.157)\end{array}$ & $\begin{array}{c}1.869^{* * *} \\
(0.692)\end{array}$ & $\begin{array}{r}-0.059 \\
(0.695)\end{array}$ & $\begin{array}{r}-0.272 \\
(0.591)\end{array}$ & $\begin{array}{c}0.47 \\
(0.621)\end{array}$ & $\begin{array}{c}0.016 \\
(0.058)\end{array}$ & $\begin{array}{c}0.016 \\
(0.037)\end{array}$ & $\begin{array}{c}-1.258^{* * *} \\
(0.665)\end{array}$ & $\begin{array}{c}0.271 \\
(0.704)\end{array}$ & $\begin{array}{c}1.734^{* * *} \\
(0.667)\end{array}$ & $\begin{array}{c}2.397^{* * * *} \\
(0.784)\end{array}$ \\
\hline LNGDP2 & $\begin{array}{l}-0.036 \\
(0.049)\end{array}$ & $\begin{array}{c}0.009 \\
(0.055)\end{array}$ & $\begin{array}{c}-0.090^{* *} \\
(0.043)\end{array}$ & $\begin{array}{c}-0.079^{*} \\
(0.043)\end{array}$ & $\begin{array}{l}-0.052 \\
(0.037)\end{array}$ & $\begin{array}{l}-0.03 \\
(0.039)\end{array}$ & $\begin{array}{c}-0.084^{* *} \\
(0.041)\end{array}$ & $\begin{array}{c}-0.085^{* *} \\
(0.041)\end{array}$ & $\begin{array}{l}-0.048 \\
(0.042)\end{array}$ & $\begin{array}{l}-0.02 \\
(0.044)\end{array}$ & $\begin{array}{c}-0.092^{* *} \\
(0.041)\end{array}$ & $\begin{array}{l}-0.069 \\
(0.046)\end{array}$ \\
\hline Observations & 221 & 221 & 221 & 221 & 221 & 221 & 221 & 221 & 221 & 221 & 221 & 221 \\
\hline Country FE & YES & YES & YES & YES & YES & YES & YES & YES & YES & YES & YES & YES \\
\hline Year FE & YES & YES & YES & YES & YES & YES & YES & YES & YES & YES & YES & YES \\
\hline Wald F-statistic & 1.536 & 1.421 & 1.716 & 1.53 & 4.764 & 4.256 & 1.397 & 1.374 & 3.814 & 3.706 & 4.253 & 4.097 \\
\hline Hansen J test (p-value) & 0.2144 & 0.1983 & 0.2832 & 0.2774 & 0.2542 & 0.2518 & 0.2656 & 0.2609 & 0.2365 & 0.2344 & 0.3091 & 0.3087 \\
\hline R-squared & 0.9758 & 0.9683 & 0.9565 & 0.9342 & 0.9757 & 0.9718 & 0.9687 & 0.9295 & 0.9766 & 0.9709 & 0.9738 & 0.9723 \\
\hline
\end{tabular}

Note: (1) The Wald F statistic is a joint significance test of the instruments. The Hansen J ( $\mathrm{p}$-value) is a test of overidentification restrictions in the network equation. (2) ${ }^{*} \mathrm{p}<0.1 ;{ }^{* *} \mathrm{p}<0.05$;

*** $\mathrm{p}<0.1$. (3) Robust standard errors in parenthesis. 
The regression results of column 5 in Tables 6 and 8 show that that eigenvector centrality (LNEigenvector) of the OBOR trade network has a positive impact on the per capita $\mathrm{CO} 2$ emissions, with the estimation coefficients for low-income countries being insignificant (see Tables 6 and 8). However, the research of [9] finds that eigenvectors are negative for countries in the world trade network. After the total trade volume (LNTrade) is introduced, the coefficient for LNEigenvector remains not significant for the low-income countries (see column 6 in Tables 6 and 8). The discrepancies between our findings with that in [9] could be explained in the following way: unlike the countries in the world trade network, the central country nodes and many other important country nodes of the OBOR trade network (such as China, Russia, the United Arab Emirates, India and Malaysia) mainly export energy, raw materials, and the products with low value-added technology. The more closely connected with the central country nodes, the more increase of one country's CO2 emissions. In addition, since the low-income countries usually have less connection with the central country nodes of the OBOR trade network, the positive impact of direct and indirect effects of trade on the environmental quality is not significant.

As discussed in Section 1, we include more network indicators comparing to [9] to study the additional impacts on $\mathrm{CO} 2$ emissions. Columns 7 to 12 show the estimation results for each of these additional indicators. In the following paragraphs, we highlight the interesting results and discuss accordingly.

The clustering coefficient (LNClustering) has a significant positive impact on $\mathrm{CO} 2$ emissions in low-income countries of the OBOR trade network but a negative impact on $\mathrm{CO} 2$ emissions for the high-income countries (see column 7 in Tables 7 and 8). In addition, the value of the coefficient for LNClustering in low-income countries is significantly increased after the total trade volume (LNTrade) is introduced (see column 8 in Table 8). The clustering coefficient (LNClustering) reflects the agglomeration of country nodes in the trade network. For low-income countries, which are located in the middle and lower tiers of the value chain, LNClustering reflects their dependence on large trading countries and therefore, trade does not effectively improve their environmental quality. For the high-income countries, LNClustering reflects the "rich man's club" phenomenon, which means that the optimization of the value chain among them leads to the improvement of environmental quality.

The results of column 11 of Tables 6 and 7 show that LNWoutdegree has a positive effect on CO2 emissions for the all-country sample (Table 6) and high-income country sample (Table 7). Meanwhile, the estimation coefficient of LNWoutdegree for low-income countries is significantly negative (see Table 8). To be exact, for every $1 \%$ increase in export strength, the CO2 emissions of low-income countries will fall by $0.903 \%$. This indicates that when a high-income country node in a trade network acts as an importer, the stronger its import trade links are, the greater its $\mathrm{CO} 2$ emissions will be, which will have a negative impact on its environmental quality.

Concerning the direct effect of trade, we find that the trade volume (LNTrade) has a positive relationship with $\mathrm{CO} 2$ emissions in most of the regressions, which is consistent with the conclusions of [9]. However, when combined with LNClustering variable, the trade has a negative impact on CO2 emissions for all-country and high-income country samples in the trade network, which indicates that the "rich man's club" phenomenon promotes trade to improve the environmental quality of high-income countries, but low-income countries cannot achieve similar benefits. This result basically is similar to the effects of other network indicators discussed previously.

For the scale effect, the increase in unit GDP (LNGDP) will lead to the increase of the pollution level in countries in the trade network, which is consistent with the conclusions of [9]. In addition, from the estimation coefficient of $L N G D P 2$, the environmental Kuznets curve is valid in the three samples of countries in the OBOR trade network. It shows an inverted U-shaped curve, which reveals that environment deteriorates with the economic growth.

With regard to the technology effect, the net inflow of FDI as a share of GDP (LNFDI) does not improve the environmental quality of the countries in the OBOR trade network. This is because the majority of high-income countries in the OBOR trade network, such as China, Russia, Thailand and 
Malaysia, are in the transformation stage of upgrading industrial structure. The effect of technological spillovers and knowledge spillovers on environmental quality has not been fully materialized. Furthermore, the FDI inflows to low-income countries are mostly used for infrastructure construction and industrial transformation. The energy consumption of the production and processing industries caused by industrial transfer is relatively high, which leads to an increase in $\mathrm{CO} 2$ emissions.

Regarding the composition effect, the proportion of industrial value in GDP (LNIndustry) improves environmental quality in all three samples. This is partly due to the incomplete industrial system for most of countries in the OBOR trade network, the composition effect promotes the development of industrial sectors and improve the environmental quality. The high-income countries (such as China, Russia, India, etc.) of the OBOR trade network are upgrading their industrial structure and the low-income countries are improving their industrial technology. All these measures are conducive to reducing carbon emissions and improving the environmental quality of these countries.

\section{Conclusions}

By applying the network analysis method to the bilateral import and export data of the United Nations Conference on Trade and Development from 2005-2016, this paper selected 66 countries of the OBOR trade network and investigated the structural characteristics of the trade network and the resulting impact on the environment. We found that China is one of the central country nodes and holds the absolute core position in the OBOR trade network. After the OBOR initiative was put forward, China's participation and bargaining power in the trade network were further improved. In addition, we divided the 66 countries along the OBOR into two groups, high- and low-income countries. Within the category of high-income countries, the correlation between network structure characteristics and $\mathrm{CO} 2$ emissions is relatively clear. From the perspective of the time dimension, the structural characteristics of the trade network are consistent with the trend of $\mathrm{CO} 2$ emissions from 2005 to 2014.

Furthermore, we used 3SLS to analyze the environmental effects of the OBOR trade network. The results showed that the status of the country nodes in the trade network has a significant impact on their $\mathrm{CO} 2$ emissions, while there are some differences between high- and low-income countries. We found that indirect effects of the OBOR trade network mainly improve environmental quality in low-income countries but have a negative impact on the environment of high-income countries, which is consistent with the results of [9] for the world trade network. However, the technology effect captured by FDI does not improve the environmental quality of the countries in the OBOR trade network, which is contrary to the results of [9]. Moreover, the environmental Kuznets curve was established and tested for the data set.

Our study can be applied to international trade and environmental economics. The trade volume and the position of a country in the OBOR trade network will affect the country's environmental quality. Therefore, national policy makers should focus on the quality of the economy and promote the optimization of the industrial structure. A stronger environmental policy may help improve the environmental quality, especially in developing countries. Developing countries should implement strict environment control policies and actively promote trade liberalization of environmentally friendly products, through which energy consumption and carbon emissions will be reduced to improve the environmental quality. In addition, the structure of the trade networks involving certain industries and their related environmental effects may be studied in the future.

Author Contributions: Conceptualization, S.C. and Q.Q.; methodology, S.C. and Q.Q.; software, S.C.; validation, S.C. and Q.Q.; formal analysis, S.C. and Q.Q.; investigation, S.C.; resources, S.C.; data curation, S.C.; writing—original draft preparation, S.C.; writing_-review and editing, Q.Q.; visualization, S.C.; supervision, Q.Q.; project administration, Q.Q.; funding acquisition, S.C. All authors have read and agreed to the published version of the manuscript.

Funding: This work is supported by the National Social Science Fund of China under grant [18CJY038], the General Project of the Ministry of Education under grant [17YJC790104], and the General Project of Shaanxi Provincial Department of Education under grant [19JK0322]. 
Conflicts of Interest: The authors declare that there are no conflicts of interest regarding the publication of this paper.

\section{References}

1. Yang, F.; Yang, M. Greening the one belt and one road initiative. Mitig. Adapt. Strateg. Glob. Chang. 2019, 24, 735-748. [CrossRef]

2. Wiedmann, T.; Lenzen, M. Environmental and social footprints of international trade. Nat. Geosci. 2018, 11, 314-321. [CrossRef]

3. Snyder, D.; Kick, E.L. Structural position in the world system and economic growth, 1955-1970: A multiple-network analysis of transnational interactions. Am. J. Sociol. 1979, 84, 1096-1126. [CrossRef]

4. Smith, D.A.; White, D.R. Structure and dynamics of the global economy: Network analysis of international trade 1965-1980. Soc. Forces 1992, 70, 857-893. [CrossRef]

5. Serrano, M.A.; Boguñá, M. Topology of the world trade web. Phys. Rev. E Stat. Nonlinear Soft Matter Phys. 2003, 68, 015101. [CrossRef] [PubMed]

6. Squartini, T.; Fagiolo, G.; Garlaschelli, D. Randomizing world trade. I. A binary network analysis. Phys. Rev. E Stat. Nonlinear Soft Matter Phys. 2011, 84, 046117. [CrossRef]

7. Xu, H.; Long, C. The QAP weighted network analysis method and its application in international services trade. Phys. A Stat. Mech. Appl. 2016, 448, 91-101. [CrossRef]

8. May, D.E. An international trade network analysis of the environment. Asia Pac. J. Account. Econ. 2009, 16, 271-284. [CrossRef]

9. Aller, C.; Ductor, L.; Herrerias, M.J. The world trade network and the environment. Energy Econ. 2015, 52, 55-68. [CrossRef]

10. Hakimi, A.; Hamdi, H. Trade liberalization, FDI inflows, environmental quality and economic growth: A comparative analysis between Tunisia and Morocco. Renew. Sustain. Energy Rev. 2016, 58, 1445-1456. [CrossRef]

11. Essandoh, O.K.; Islam, M.; Kakinaka, M. Linking international trade and foreign direct investment to $\mathrm{CO}_{2}$ emissions: Any differences between developed and developing countries? Sci. Total Environ. 2020, 712, 136437. [CrossRef]

12. Fernández-Amador, O.; Francois, F.; Tomberger, P. Carbon dioxide emissions and international trade at the turn of the millennium. Ecol. Econ. 2016, 125, 14-26. [CrossRef]

13. Frankel, J.A.; Rose, A.K. Is trade good or bad for the environment? Sorting out the causality. Rev. Econ. Stat. 2005, 87, 85-91. [CrossRef]

14. Copeland, B.R.; Taylor, M.S. Trade, growth, and the environment. J. Econ. Lit. 2004, 42, 7-71. [CrossRef]

15. Wang, W.; Li, Z.; Cheng, X. Evolution of the global coal trade network: A complex network analysis. Resour. Policy 2019, 62, 496-506. [CrossRef]

16. Sun, Q.P.; Geng, Y.F.; Ma, F.; Wang, C.; Wang, B.; Wang, X.; Wang, W.L. Spatial-Temporal evolution and factor decomposition for ecological pressure of carbon footprint in the one belt and one road. Sustainability 2018, 10, 3107. [CrossRef]

17. Hafeez, M.; Yuan, C.H.; Shahzad, K.; Aziz, B.; Iqbal, K.; Raza, S. An empirical evaluation of financial development-carbon footprint nexus in One Belt and Road region. Environ. Sci. Pollut. Res. 2019, 26, 25026-25036. [CrossRef]

18. Johnson, D.L.; Ambrose, S.H.; Bassett, T.J.; Bowen, M.L.; Winter-Nelson, A.E. Meanings of environmental terms. J. Environ. Qual. 1997, 26, 581-589. [CrossRef]

19. Bhattacharya, K.; Mukherjee, G.; Saramäki, J.; Kaski, K.; Manna, S.S. The international trade network: Weighted network analysis and modelling. J. Stat. Mech. Theory Exp. 2008, 41, 139-147. [CrossRef]

20. Fagiolo, G.; Reyes, J.; Schiavo, S. The evolution of the world trade web: A weighted-network analysis. J. Evol. Econ. 2010, 20, 479-514. [CrossRef]

21. Antweiler, W.; Copeland, B.R.; Taylor, M.S. Is free trade good for the environment? Am. Econ. Rev. 2001, 91, 877-908. [CrossRef]

22. Shafik, N.; Banerjee, A.; Forder, J. Economic development and environmental quality: An econometric analysis. Oxf. Econ. Pap. 1994, 46, 757-773. [CrossRef] 
23. Levin, A.; Lin, C.; Chu, C.S. Unit root tests in panel data: Asymptotic and finite-sample properties. J. Econom. 2008, 108, 1-24. [CrossRef]

24. Choi, I. Unit root tests for panel data. J. Int. Money Financ. 2001, 20, 249-272. [CrossRef]

25. Maddala, G.S. A comparative study of unit root test with panel data and a new sample test. Oxf. Bull. Econ. Stat. 1999, 61, 631-652. [CrossRef]

(C) 2020 by the authors. Licensee MDPI, Basel, Switzerland. This article is an open access article distributed under the terms and conditions of the Creative Commons Attribution (CC BY) license (http://creativecommons.org/licenses/by/4.0/). 